\title{
The Dynamics of the Social Network of Urban Farmers in Subak Sembung Denpasar
}

\author{
Dwi Putra Darmawan, Gede Mekse Korri Arisena, Ni Wayan Febriana Utami, Anak Agung Keswari
} Krisnandika

Faculty of Agriculture, Udayana University, Denpasar, Bali

\begin{abstract}
A reduction in the number of farmers, urbanization, limited land, poverty, environmental changes, uncertainty of production results and limited access to resources are still being serious problems and have a direct effect on farmers' income. Facing that conditions, in order to survive, social networks are one of the adaptation strategies implemented by the farmers. This research aimed to examine the social phenomena of urban farmers in Subak Sembung, Denpasar City and to try to find the rational actions conducted by the farmers in dealing with economic problems that occurred. This research was conducted in March - October 2020. The location of Subak Sembung was chosen because Subak Sembung is a subak that still exists in Denpasar City. The total samples were $20 \%$ of the total population, which is 40 people. This research used qualitative and quantitative approaches. The qualitative method in this research was using a case study, while the quantitative method used a survey. The research results showed that social, economic and environmental changes that occurred caused urban farmers to adapt. The adaptation pattern that was implemented was to apply a survival strategy and a double income pattern. The economic condition of urban farmers in Denpasar City was very good. The social network that was formed is a social network to fellow farmers, farmers to management subak, and farm shops. Action rationalism was performed in the context of improving the economy, working relations, and preserving culture.
\end{abstract}

\section{Keywords}

Social network, urban farmers, water-control systems (Subak).

Darmawan, D. P., Arisena, G. M, K., Utami, N. W. F. and Krisnandika, A. A. K. (2021) "The Dynamics of the Social Network of Urban Farmers in Subak Sembung Denpasar", AGRIS on-line Papers in Economics and Informatics, Vol. 13, No. 2, pp. 51-58. ISSN 1804-1930. DOI 10.7160/aol.2021.130204.

\section{Introduction}

The decrease of farmers, urbanization, limited land, poverty, environmental changes, uncertainty of production results and limited access to resources are still serious problems and have a direct effect on farmers' income. Facing that conditions, many farmers have implemented various strategies to survive in the midst of the rapid development of other sectors in the Denpasar City. Social networks are one of the adaptation strategies implemented by the farmers.

The research results by Risman et al. (2019) stated that the social network strategy was a survival strategy conducted by establishing relations both formally and with the social environment, for example borrowing money from retainer, friends, family, and even seaweed barter. This strategy was used to solve the socioeconomic problems of seaweed farmers, whether it was education problems, resistance in working, or income. Furthermore, Gandi et al. (2017) stated that the actors involved in the social network of the agricultural bonded system included farmers, wholesaler, traders and the government. Those four actors were tied together with trust as their asset. Social networks focused on social relations or objective patterns of bonds that connected members.

The urban farmers in Denpasar City in performing their lives have guidelines that were used to legitimize their actions to interpret their relations patterns with nature. These guidelines were passed down from one generation to the next and at a later stage became the forerunner of their growing culture. The adaptation process is one part of the process of cultural evolution. Meanwhile, cultural evolution is a sequence of human efforts to adapt or respond to changes in the physical 
and social environment that occurred temporally.

Facing that conditions, the farmers in Denpasar City need to perform adaptation strategies for their survival. In facing economic problems, farmers must take advantage of various strategies, one of them is the social network strategy. This method was an adaptation strategy performed by farmers in Denpasar City for their survival. Furthermore, according to Lestari (2017) stated the general factors that affect adaptability, were: education, income and health. There were several specific factors that affect adaptive capacity, which were the level of vulnerability, institutional, knowledge and technology. It was reinforced by research by Sumaryanto (2012) which stated that adaptation capacity affected the level of vulnerability through two line, which were directly and indirectly. The indirect line was through a mechanism of potential impact reduction, while the direct line included the step of coping strategies in resolving problems related to the perceived vulnerability.

The innovation of this research was to find the function of social networks not only as a social relation, but also to find out the economic motives in it. So that, in the end social networks can help farmers to access resources more easily both in the agricultural and non-agricultural sectors. Another innovation in this research was that the research on farmer adaptation strategies had been done a lot, but it did not discuss more specifically about social networks as a rational action for farmers.

This research aimed to examine the social phenomena of urban farmers in Denpasar City and try to find out the rational actions taken by farmers in dealing with economic problems that occurred. In detail, the aimed of this research were (1) to analyze the adaptation patterns performed by farmer households in dealing with changes of the land usage (2) to analyze the economic conditions that occurred in urban farmers in Denpasar City (3) to analyze the formation of social networks of urban farmers in Denpasar City (4) to analyze the rationality of action in networked urban farmers in Denpasar city.

\section{Materials and methods}

This research was conducted at the end of March 2020 to October 2020. The city of Denpasar was chosen because it is the capital of Bali Province (Bali Province is the main tourist destination in Indonesia) where most of the population work in the tourism and commercial sectors. Uniquely, in Denpasar, there is still an urban farming population. The population of urban farmers that can be found in Denpasar City is in Subak Sembung. Subak Sembung is one of the surviving subaks in the midst of Denpasar City. In addition, the Subak Sembung area still has 115 hectares' area which administratively includes Peguyangan Village, North Denpasar Sub-district. The population in this research were 200 farmers who manage/members of the Subak Sembung Denpasar City. The number of samples was $20 \%$ of the total population or about 40 people.

In this research, data were collected through observation and interviews. The observation technique that used was direct observation, to observe or watch directly, hear, and feel the object of the problem that occurred in Subak Sembung. Researchers as the data collectors participated and were involved in activities that were the source of observations. While engaged in activities, researchers can watch, feel, listen to various things that were directly related to the data to be collected. Through this way, researchers believed to watch and observe by themselves how the Social Networking system that occurred in Subak Sembung. The interview technique that used was structured interviews, which is interviews with distantardization. Where researchers had prepared questions that will be asked to all respondents. Question and answer procedures, style, and wording in questions had also been arranged. This technique was used to obtain direct data from informants.

The aim one, two, three and four were analyzed by qualitative analysis. Qualitative analysis based on the opinions and ideas of the people that being studied, and seeing as closely as possible the target of the study, which was farmers in Subak Sembung, Denpasar City. The quantitative data collected in this research will be used to support qualitative analysis. Before being analyzed, all the data obtained was checked to minimize the possibility of errors or follow the following procedure (1) editing, which is the process of examining data for possible errors (2) coding, which is classifying respondents' answers with certain codes (3) tabulation, which is the arrangement of data into tables.

\section{Results and discussion}

The adaptation pattern that performed by the farmer households in facing the changes of land usages

The results showed that $35 \%$ of farmer' family members work outside the agricultural sector, such 
as in the service and tourism sector, $27.5 \%$ stated that there were some members of farm families who worked outside the agricultural sector, and $37.5 \%$ members of farmer families who worked in agricultural sector (Table 1).

\begin{tabular}{|c|c|c|}
\hline No & Adaptation pattern & $\begin{array}{l}\text { Number } \\
\text { of people }\end{array}$ \\
\hline \multirow[t]{5}{*}{1} & $\begin{array}{l}\text { All family } \\
\text { of farming sector. }\end{array}$ & \\
\hline & . $\quad$ Yes & 15 \\
\hline & . $\quad$ No & 14 \\
\hline & . A few & 11 \\
\hline & Total & 40 \\
\hline \multirow[t]{4}{*}{2} & The wives also earn outside the agricultural sector & \\
\hline & . $\quad$ Yes & 9 \\
\hline & No & 31 \\
\hline & Total & 40 \\
\hline \multirow[t]{4}{*}{3} & Family members mobilized to help farming & \\
\hline & . $\quad$ Yes & 25 \\
\hline & . $\quad$ No & 15 \\
\hline & Total & 40 \\
\hline \multirow[t]{4}{*}{4} & $\begin{array}{l}\text { Head of the Family did various jobs to earn } \\
\text { additional income }\end{array}$ & \\
\hline & . $\quad$ Yes & 17 \\
\hline & . $\quad$ No & 23 \\
\hline & Total & 40 \\
\hline \multirow[t]{4}{*}{5} & $\begin{array}{l}\text { Performing product diversification pattern } \\
\text { according to the market needs }\end{array}$ & \\
\hline & . $\quad$ Yes & 33 \\
\hline & . $\quad$ No & 7 \\
\hline & Total & 40 \\
\hline \multirow[t]{4}{*}{6} & $\begin{array}{l}\text { Performing the last alternative which was leaving } \\
\text { agriculture. }\end{array}$ & \\
\hline & . $\quad$ Yes & - \\
\hline & No & 40 \\
\hline & Total & 40 \\
\hline
\end{tabular}

Source: processed from the primary data, 2020

Table 1: The adaptation that performed by the farmer households in facing the changes of land usage.

In order to adapt to urban conditions, farmers in Subak Sembung applied a survival strategy and a double income pattern. The patterns of survival strategies that performed by Subak Sembung farmers were 1) family members were mobilized to help farming $(62 \%), 2)$ the head of the family did a variety of jobs to earn additional income (42\%), and 3) performed a product diversification pattern that match to the market needs $(82 \%)$.

The research result by $\mathrm{Li}$ and $\mathrm{Hu}$ (2014) stated that in order to survive in limited land, farmers tried to use these three main survival strategies, which were competitive differentiation, cooperation and product diversification. Furthermore, Christopher and Helena (2018) showed that Ileje migrants adopted a survival strategy, which was the intensification of non-traditional commercial crops such as corn, rice, millet and banana. The research results by Sheil and Graykowski (2012) added that small and medium farms can be commercially competitive by using a survival adaptation strategy through a collaboration between farmers and cooperatives.

Besides the survival strategy, the strategy used by the farmers in Subak Sembung also used a double income pattern strategy. It can be seen more clearly in table 1, which were 1) several family members working outside the agricultural sector $(27.5 \%), 2)$ all family members working outside the agricultural sector (37.5\%), 3 ) the wives earn outside the agricultural sector $(22 \%)$, and 4$)$ the head of the family did various jobs to get additional income (42\%).

The research results of Sumarti (2007) stated that the double income strategy of households as an attempt to improve the economic welfare of farmers in various lining of smallholder plantations, needs to be placed in a local multilevel (multiple level) framework, both at the farm household level and at the local community and government level. A different opinion was expressed by Abdurrahim (2014) that the double income strategy "formed" through the development of MPA-COREMAP (Alternative Livelihood - Coral Reef Rehabilitation and Management Project) did not going as expected. After only three years of development, only 9 pokmas (community groups) out of 19 pokmas still survive and continue the MPA development program. Providing financial capital in the form of a revolving fund; physical capital in the form of production tools and infrastructure; and human capital through various trainings was not enough to build a sustainable livelihood system. Social capital in the form of trusts, networks, and institutions that can drive community' activities sustainably, relatively non-existent.

The good news was that all respondents do not have desire to stop being a farmer because farming can still provide additional income for the family, farmers do not have skill in other fields, farming is a hobby and the land that currently available is still productive to cultivate.

\section{Economic condition happening to the urban farmer in Denpasar City}

The The economic condition of farmers in Subak Sembung indicated that $95 \%$ of respondents own motorbikes and $82.5 \%$ own cars. Thus, if it 
was seen from the availability of transportation facilities, the farmers in Subak Sembung can be said to be in prosperous category (Table 2). If it was seen generally, the economic conditions of farmers in Subak Sembung were not in the poor category, according to Isdijoso et al., (2016) the criteria for measuring poverty according to the BKKBN, the BPS poverty measurement criteria on PSE05 and the BPS poverty measurement criteria on PPLS 2008. In line with research by Sa'diyah and Fitrie (2012) which stated that vehicle ownership, most of them also already have a motorbike, but here the motorbikes' function not only as the family transportation but were also used to earn additional income, for example motorcycle taxis, selling vegetables.

\begin{tabular}{|c|c|c|}
\hline No & Economic Condition & $\begin{array}{r}\text { Number } \\
\text { of People }\end{array}$ \\
\hline \multirow[t]{4}{*}{1} & Have Motorbike & \\
\hline & . $\quad$ Yes & 37 \\
\hline & . $\quad$ No & 3 \\
\hline & Total & 40 \\
\hline \multirow[t]{4}{*}{2} & Have Car & \\
\hline & - $\quad$ Yes & 33 \\
\hline & . $\quad$ No & 7 \\
\hline & Total & 40 \\
\hline \multirow[t]{4}{*}{3} & Source of Farming Capital & \\
\hline & Own capital & 38 \\
\hline & - Capital from caretaker & 2 \\
\hline & Total & 40 \\
\hline \multirow[t]{4}{*}{4} & $\begin{array}{l}\text { Have ever owed money from wholesaler or farm } \\
\text { shops }\end{array}$ & \\
\hline & . $\quad$ Yes & 5 \\
\hline & . $\quad$ No & 35 \\
\hline & Total & 40 \\
\hline
\end{tabular}

Source: processed from the primary data, 2020

Table 2: Economic condition happening to the urban farmers in Denpasar City.

The research results also showed that 95\% of the respondents had source of farming capital came from their own capital and $87 \%$ of respondents stated that they never owed money to wholesaler or agricultural shops. In other words, farmers in Subak Sembung had been able to be economically independent to performed their business (Table 2).

Emery (2015) research results that independence had the effect of covering the structural dependency faced by farmers (such as dependence on creditors). Further strengthened by the results of research by Sucitayasa et al., (2018) the management of vegetable cultivation that performed by farmers in Denpasar City was still traditional. The independence level of farmers in managing vegetable farming in Denpasar City on the capital/ finance, production, and marketing aspects was evenly in the medium category. Further research by Djuliansah et al., (2020) found different results for soybean farmers in Pancatengah Sub-district which were still unable to perform soybean farming independently without government assistance. This was due to the absence of selling assurance and price guarantees as well as fear of crop failure. As a result of their inability to resolve pests and soybean plants diseases.

\section{The establishment of urban farmers' social network in Denpasar City}

According to Parasmo and Utami (2017) social networks in a community showed the type of social relations that was bound on the basis of kinship identity, race, ethnicity, friendship, proximity or on the basis of certain interests and showed a social relation that occurred, so that it showed more on the process than form. Furthermore, Ramirez (2013) described each type of social network had impacts on technology diffusion differently, because the relation between individuals that involved in technology occurred in diverse social contexts. The collaboration of individuals with technology can occur in three social settings: kinship (family), landlord-tenant relations (occupation), and affiliation (social association).

The social network pattern of urban farmers in Subak Sembung was a relations to fellow farmers, which were: 1) a relation of interest (borrowed a tractor and work equipment), 2) a relation of giving (gave/asked for seeds to other farmers), 3) a relation of feelings (gathered after work with other farmers in the fields to exchange information), 4) economic motivation (bought other farmers' garden products for personal consumption, discussed and seek information on grain prices, offered to help other farmers), and 5) non-economic motivation (tractor rental information).

The relations between farmers and management Subak, which were: 1) power relations (coordination with Kelian Subak/the chairman of Subak, determination of rice planting period, and the distribution of water), 2) character of open relations (subak member meetings and mutual cooperation), and 3) economic motivation (seeds availability and subsidized fertilizers). The relations between farmers and agricultural shops, which were 1) the character of open relations (established good relations) and 2) economic motivation (price information, fertilizer buying, and medicines). The relations between farmers and wholesaler, which was economic motivation (interaction 
with wholesaler occurred based on the highest supply or according to agreement). In detail, the knot of urban farmers' social network in Subak Sembung can be seen in Figure 1.

The pattern knot of social network in each case will be different, all will be influenced by the characteristics and real conditions of each research location. The research results by Sukmana and Sari (2017), stated that the social network knot formed in the practice of hidden prostitution in the Songgoriti tourist area, Batu City, involved various stakeholders, which were: government officials, the Villa Supo association, PSK service users, villagers who own villas, motorcycle taxi drivers (tour-guide), owners of karaoke and billiards places, commercial sex workers (CSWs), and the local community. These stakeholders created a mutually supportive and beneficial network chain, especially economically. Furthermore, the research results of Maanana et al., (2015), described three types of social networks that was built between farmers and sellers of sweet orange, Kisar, which were trust, cooperation, and social exchange. This collaboration developed trust between farmers and sellers who determine the price of the sweet orange, Kisar. Finally, there was a sense of mutual help, honesty and a harmonious relation between farmers and sellers.

The rationality of actions in networking urban farmers in Denpasar City

According to Hidayat (2016) stated that the rationality of an idea or action was always associated with the suitability, accuracy, or acceptability of the idea or action with mutually agreed norms. Furthermore, Isfandiar (2015) stated that rationality and common sense (idea) were the key methods used to analyze data in a systematic observation. In economics, sociology and political science, a decision or situation was often called rational, if it was aimed at optimization in pursuing a goal.

Basically, a social network was a rationality of action in the form of social relations which were in it points/knots that connected to other points/knots. Previously, it had been explained that the actors who play a role in the social network of farmers in Subak Sembung had various relations (interests, presents, feelings, economic motivation, non-economic motivation, power and the character of open relations).

The rationalism of the actions taken by the Subak Sembung farmers in improving the economy were 1) family members working outside the agricultural sector, 2) mobilizing family members to help businesses, 3) family heads doing various kinds of work to increase income, 4) performing a pattern of product diversification in accordance with market needs, 5) looking for information on the grain price and wholesaler, and 6) looking for information on the availability of subsidized seeds and fertilizers.

Besides the rationalism of action in the economic field, farmers in Subak Sembung also took action rationalism in working relations and conserving culture. The action rationalism in the work relations performed by Subak Sembung farmers was 1) borrowed farming equipment from fellow farmers, 2) got/asked for seeds from other farmers, and 3) while resting in the fields, farmers gathered with other farmers to exchange farming

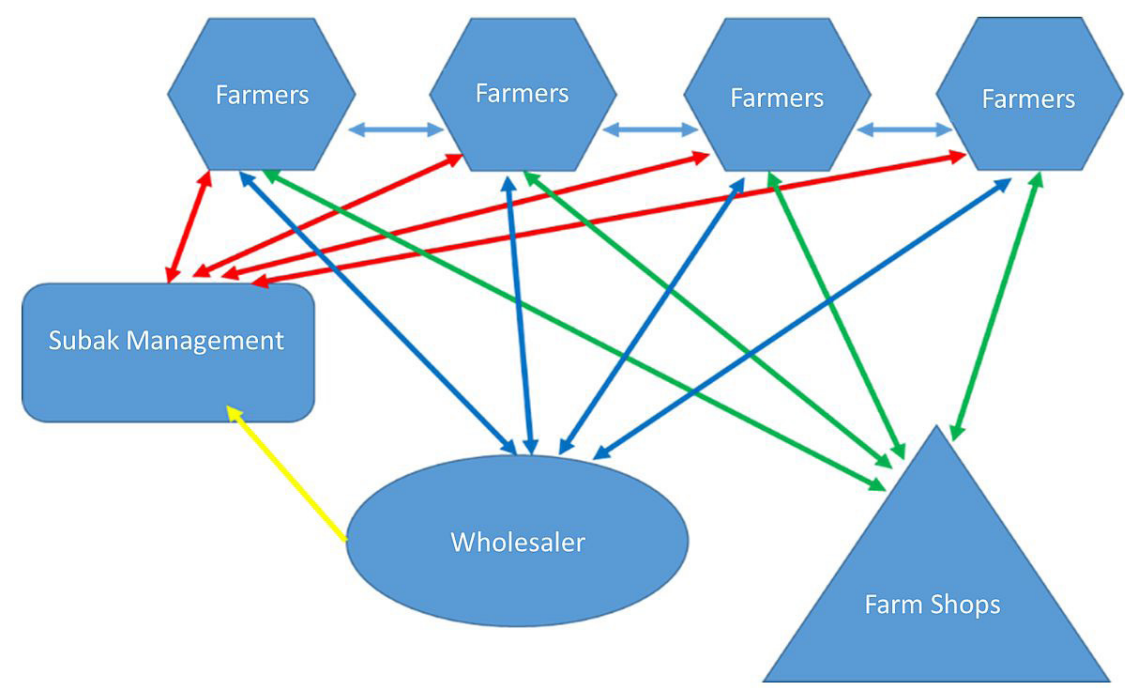

Source: own processing

Figure 1: The knot of urban farmers' social network in Subak Sembung. 
information. Action rationalism in conserving culture was also performed by Subak Sembung farmers, which were 1) coordinated with subak kelian/subak chairman about determining the rice planting period and water distribution, 2) subak members' meeting, 3) mutual cooperation, and 4) coordinated in performing ceremonial activities.

In line with research result by Adriani (2015) which stated that social rationality was performed by farmers by diversifying jobs. Most of the farmers in the research area developed other farming businesses besides rice, which were soybean and long bean farming. This was the impact of economic rationality, which was performed to overcome low farm income and overplus of working time for farmer families. Furthermore, the research results of Mutiar et al., (2018), described the rational instrumental actions of fishermen in relation to fishing marketing. These actions were actions that lead to the interests to be achieved. That is, they did the action without being noticed by the boss. The strategy of "cheating on the baskets" was a phenomenon that occurred among the small fishermen of Karangsong.

\section{Conclusion}

The change of social, economic, and environmental that occurred cause urban farmers to adapt. The adaptation pattern that performed was to apply a survival strategy and a double income pattern. The economic condition of urban farmers in Denpasar City was very good. The social network that formed was a social network to fellow farmers, farmers to subak wholesaler management, and agricultural shops. In addition, there was a oneway social network between wholesaler to subak management. Action rationalism was performed

Corresponding authors

Dr. Gede Mekse Korri Arisena, S.P., M.Agb

Faculty of Agriculture, Udayana University, Jalan P.B. Sudirman, Denpasar, Bali

Phone:+62 819-4486-4138,E-mail: korriarisena@unud.ac.

\section{References}

[1] Abdurrahim, A. Y. (2014) "Strategi Nafkah Ganda "Bentukan" Rumah Tangga Pedesaan Pesisir Di Kabupaten Bintan, Jurnal Sosiologi Refleksi, Vol. 9, No. 1, pp. 1-22. E-ISSN 2528-4177, ISSN 1978-0362. (In Indonesian).

[2] Adriani, D. (2015) "Rasionalitas Sosial-Ekonomi dalam Penyelesaian Pengangguran Terselubung Petani Sawah Tadah Hujan", MASYARAKAT: Jurnal Sosiologi, Vol. 20, No. 1, pp. 43-58. E-ISSN 2460-8165, ISSN 0852-8489. DOI 10.7454/mjs.v20i1.4760. (In Indonesian).

[3] Christopher, A. M. and Helena, E. M. (2018) "Survival strategies and livelihood diversification of Ileje Migrants in Mbozi District, Southern Tanzania, Journal of African Studies and Development, Vol. 10, No. 4, pp. 43-50. ISSN 2141-2189. DOI 10.5897/jasd2018.0490. in the context of improving the economy, working relations, and conserving culture.

The thing that became an important concern was the social network pattern that occurred in Subak Sembung, which was between farmers and wholesaler. Most of the farmers sell their products economic goals for both parties. The relations between farmers and wholesaler produced mutually beneficial economic exchanges. Wholesaler did not have the role of creditor/owner of capital and this The policy implication that can be performed by both the Denpasar City government and the Bali Provincial Government was to create a joint forum between farmers and wholesaler, institutions. With the existence of this forum, it can be used as a work ecosystem that can create more beneficial results for both parties. This forum is also expected to act as legality to receive terial assistance and assistance with knowledge the welfare of both parties.

\section{Acknowledgements}

We thanked the prajuru and kelian of subak sembung for the precious support and discussion for this study. We also express our gratitude for Udayana University for the fund provided in conducting this study through list of fund practitioner the non-tax fund receipt in Udayana University according to the research agreement letter number B/20-34/UN14.4.A/PT.01.05/2020. wholesaler had a strategic position 
[4] Djuliansah, D., Noor, T. I., Deliana, Y. and Rachmadi, M. (2020) "Faktor-Faktor yang Berpengaruh Terhadap Tingkat Kemandirian Petani Kedelai di Kecamatan Pancatengah Kabupaten", Pemikiran Masyarakat Ilmiah Berwawasan Agribisnis, Vol. 6, No. 2, pp. 1122-1129. E-ISSN 2579-8340. (In Indonesian).

[5] Emery, S. B. (2015) "Independence and individualism: conflated values in farmer cooperation?", Agriculture and Human Values, Vol. 32, No. 1, pp. 47-61. E-ISSN 1572-8366, ISSN 0889-048X. DOI 10.1007/s10460-014-9520-8.

[6] Gandi, G. G., Mustofa, M. S. and Luthfi, A. (2017) "Jaringan Sosial Petani Dalam Sistem Ijon Pada Pertanian Di Desa Pagenteran Kecamatan Pulosari Kabupaten Pemalang", Solidarity: Journal of Education, Society and Culture, Vol. 6, No. 1, pp. 86-95. ISSN 2252-7133. (In Indonesian).

[7] Hidayat, R. (2016) "Rasionalitas: Overview terhadap Pemikiran dalam 50 Tahun Terakhir", Buletin Psikologi, Vol. 24, No. 2, pp. 101-122. ISSN 2528-5858. DOI 10.22146/buletinpsikologi.26772. (In Indonesian).

[8] Isdijoso, W., Suyahadi, A. and Akhmadi (2016) "Penetapan Kriteria dan Variabel Pendataan Penduduk Miskin yang Komprehensif dalam Rangka Perlindungan Penduduk Miskin di Kabupaten / Kota, In G. Handoko (Ed.), "Penyusunan Draf Peraturan Pemerintah tentang Kriteria dan Tata Cara Perlindungan Penduduk Miskin", pp. 1-25. (In Indonesian).

[9] Isfandiar, A. A. (2015) "Melacak Teori Rasionalitas Ekonomi berbasis Islamic Ethics", Muqtasid: Jurnal Ekonomi Dan Perbankan Syariah, No. 6, Vol. 2, pp. 23-41. E-ISSN 2527-8304, ISSN 2087-7013. DOI 10.18326/muqtasid.v6i2.23-41. (In Indonesian).

[10] Juhaepa, R. and Tawulo, dan M. A. (2019) "Strategi Petani Rumput Laut Dalam Mengatasi Problematika Sosial Ekonomi (Studi Di Desa Larete Kecamatan Poleang Tenggara Kabupaten Bombana)", Jurnal Neo Societal, Vol. 3, pp. 896-906. ISSN 2016- 9999. (In Indonesian).

[11] Lestari, D. V. (2017) "Strategi Adaptasi Petani Tanaman Pangan Terhadap Perubahan Cuaca", In Kadir, E. A., Wahyudy, H. A. and Kurniawan, A. (Eds.) "Prociding Seminar Nasional Lembaga Penelitian", Universitas Islam Riau, pp. 150-157. [Online]. Available: https://docplayer. info/147139214-Prosiding-seminar-nasional-lembaga-penelitian-universitas-islam-riau-mitigasidan-strategi-adaptasi-dampak-perubahan-iklim-di-indonesia.html [Accessed: 20 Jan 2021]. ISBN 978-979-3793-70-2. (In Indonesian).

[12] Li, M. and Hu, J. (2014) "Study on Survival Strategies of Farmers Engage in Small-Scale Household Cultivation of Edible Mushrooms: Take Shandong Province as an Example", Modern Economy, Vol. 5, No. 12, pp. 1092-1100. E-ISSN 2152-7261, ISSN 2152-7245. DOI 10.4236/me.2014.512100.

[13] Maanana, Y., Pattiselanno, A. E. and Tuhumury, M. T. F. (2015) "Jaringan Sosial Antara Petani Dan Pedagang Jeruk Manis Kisar Di Desa Lebelau Kecamatan Kisar Utara Kabupaten Maluku Barat Daya", Jurnal AGRILAN, Vol. 3, No. 3, pp. 246-258. (In Indonesian).

[14] Mutiar, I. R., Sumarti, T. and Satria, A. (2018) "Tindakan Rasional Dan Strategi Berjejaring Rumah Tangga Nelayan Kecil". Sodality: Jurnal Sosiologi Pedesaan, Vol. 6, No. 1, pp. 32-39. (In Indonesian).

[15] Parasmo, T. H. and Utami, D. (2017) "Jaringan Sosial Pedagang Barang Antik di Kota Surabaya (Studi Deskriptif Kualitatif Tentang Pedagang Klithikan Barang Antik di Jalan Bodri Kota Surabaya), Paradigma, Vol. 5, No. 3, pp. 1-7. (In Indonesian).

[16] Ramirez, A. (2013) "The Influence of Social Networks on Agricultural Technology Adoption, Procedia - Social and Behavioral Sciences, Vol. 79, pp. 101-116. ISSN 1877-0428. DOI 10.1016/j.sbspro.2013.05.059.

[17] Sa'diyah, Y. H., and Fitrie, A. (2012) "Analisis Kemiskinan Rumah Tangga melalui Faktor-Faktor yang Mempengaruhinya di Kecamatan Tugu Kota Semarang", Diponegoro Journal of Economics, Vol. 1, No. 1, pp. 1-11. [Online]. Available: https://ejournal3.undip.ac.id/index.php/jme/article/ view/249\%0Ahttps://ejournal3.undip.ac.id/index.php/jme/article/view/249/254 [Accessed: 15 Feb. 2021]. (In Indonesian). 
[18] Sheil, F. J., and Graykowski, J. J. (2012) "Family Farm Survival Strategies: The Small Farm Viability Project", 3 Notre Dame J.L. Ethics \& Pub. Pol'y 29 (1988). [Online]. Available: http://scholarship. law.nd.edu/ndjlepp/vol3/iss1/4 [Accessed: 15 Feb. 2021].

[19] Sucitayasa, I. W., Darmawan, D. P. and Ustriyana, I. N. G. (2018) "Kemandirian Petani dalam Mengelola Usahatani Sayuran di Kota Denpasar, Jurnal Agribisnis Dan Agrowisata (Journal of Agribusiness and Agritourism), Vol. 7, No. 1, p. 91. E-ISSN 2685-3809, ISSN 2301-6523. DOI 10.24843/jaa.2018.v07.i01.p10. (In Indonesian).

[20] Sukmana, O. and Sari, R. (2017) "Jaringan Sosial Praktek Prostitusi Terselubung Di Kawasan Wisata Kota Batu, Sosio Konsepsia, Vol. 6, No. 2, pp. 33-44. E-ISSN 2502-7921. DOI 10.33007/ska.v6i2.481. (In Indonesian).

[21] Sumarti, T. (2007) "Kemiskinan Petani dan Strategi Nafkah Ganda Rumahtangga Pedesaan", Sodality: Jurnal Transdisiplin Sosiologi, Komunikasi, Dan Ekologi Manusia, Vol. 1, No. 2, pp. 217-232. E-ISSN 2302-7525, ISSN 2302-7517. DOI 10.22500/sodality.v1i2.5930. (In Indonesian).

[22] Sumaryanto, N. (2012) "Strategi Peningkatan Kapasitas Adaptasi Petani Tanaman Pangan Menghadapi Perubahan Iklim, Forum Penelitian Agro Ekonomi, Vol. 30, No. 2, pp. 73-89. E-ISSN 0216-4361, ISSN 2580-2674. DOI 10.21082/fae.v30n2.2012.73-89. (In Indonesian). 